\title{
Regional Differences in the Relative Competitive Ability of Annual Bluegrass (Poa annua L.)
}

\author{
M.J. McGuan, T.K. Danneberger, ${ }^{1}$ and D.S. Gardner \\ Department of Horticulture and Crop Science, 2021 Coffey Road, The Ohio \\ State University, Columbus, OH 43210-1086
}

Additional index words. Agrostis stolonifera, competition, ecology

\begin{abstract}
Annual bluegrass (Poa annua L.) and creeping bentgrass (Agrostis palustris Huds. syn. A. stolonifera $L$.) coexist on golf greens as a dynamic ecosystem in the temperate regions of the United States. In a two year field study, the competitive ability of different populations of annual bluegrass was investigated both in and out of their native environment. In April 2000, at both The Country Club in Cleveland, Ohio, a temperate environment, and Camargo Club in Cincinnati, Ohio, a transition zone environment, 72 plugs of annual bluegrass were removed from golf greens and inserted into polyvinyl chloride pipe measuring $10.2 \mathrm{~cm}$ in diameter and $15 \mathrm{~cm}$ in length to eliminate root competition between species. Thirty-six plugs then were reestablished into one of three greens at the same golf course, and the remaining 36 plugs were transported to the opposite location and also established into one of three preselected greens. Each plug was centered in a 20.3cm-diameter sward of ' $\mathrm{L}-93$ ' creeping bentgrass to provide an initial point of reference. Competitive ability was measured as the rate of increase or decrease in average diameter of each plug. Measurements initially were taken on a bimonthly basis and then on a monthly basis for the remainder of the study. Significant $(P<0.05)$ differences in the location $x$ population interaction were seen in the first 2 months of the study and then not seen again until the last 2 months. The most frequent occurrence of significant $(P<0.05)$ differences was in the variability between greens within a particular location. At each location the native population of annual bluegrass outperformed the imported population. Differences at the beginning of the study are attributed to an additional acclimation period required by the exported population following transportation to the opposite location. From our study, annual bluegrass performance was similar across populations, suggesting that management recommendations can be made on a regional basis.
\end{abstract}

Golf greens in the northern United States and transition zone are often a mixture of annual bluegrass (Poa annua L.) and creeping bentgrass (Agrostis palustris Huds., Syn. A. stolonifera L.). These two species coexist on greens as a dynamic ecosystem, with distinct population fluctuations defining the makeup of the green at any point in time. These fluctuations are influenced by both genetic and physiological processes inherent in each species, and by environmental conditions, which can be altered to a limited extent through the use of cultural practices (Cline et al., 1993). These biological processes and environmental conditions will help to determine each species' competitive ability.

Annual bluegrass is one of the five most widely distributed plants in the world (Fenner, 1985), and can be found in every zone of adaptation in the United States (Christians, 1998). The optimum temperatures for shoot growth are between 15 and $20^{\circ} \mathrm{C}$, while optimum root growth temperatures are 10 to $15^{\circ} \mathrm{C}$ (Beard,

Received for publication 25 Nov. 2003. Accepted for publication 9 Apr. 2004. Salaries and research support provided in part by State and Federal funds appropriated to the Ohio Agricultural Research and Development Center, The Ohio State University. Journal article HCS02-39.

${ }^{1}$ To whom requests for reprints should be addressed; e-mail danneberger.1@osu.edu.
1970). It generally is classified as a weed in turfgrass systems and rarely is it seeded as an intended species. However, it will easily invade and persist in irrigated, closely mown, well-fertilized turfgrass stands and competes very well against creeping bentgrass. Annual bluegrass is more competitive in the spring and autumn, while creeping bentgrass is more competitive in the summer (Lush, 1988a). Once it invades and becomes established, annual bluegrass can quickly become the dominant species. Under proper environmental, cultural, and soil conditions, annual bluegrass has the ability to provide an extremely high-quality putting surface (Beard, 1973). As annual bluegrass becomes dominant, cultural management programs are adjusted to meet its growth requirements. Still, annual bluegrass is often considered an undesirable turfgrass species due to its susceptibility to heat, drought, disease, and low temperature stresses as well as its poor recuperative abilities.

The invasive success of annual bluegrass is due in large part to several different survival strategies. Among these are its ability to survive and produce vast numbers of seed, even at heights of cut $<3.2 \mathrm{~mm}$. This allows a viable seedbank to persist on greens, enabling the population to continually regenerate itself (Lush, 1988b, 1990). Annual bluegrass also possesses a broad genetic base, which allows for highly varied populations to occur within a relatively small area such as a single golf green (Cline et al., 1993; Lush, 1989). In fact, both annual and perennial genotypes of annual bluegrass have been documented (Gibeault, 1970; Gibeault and Goetze, 1973; Hovin, 1957; Tutin, 1957). Although generally classified as a winter annual with an upright, bunch-type growth habit, many plants exist under intense cultural management as prostrate perennials. This broad genetic variability is due in part to annual bluegrass's origin as a hybrid between Poa infirma H.B.K., an annual species, and Poa supina Schrad., a perennial (Hovin, 1957; Tutin, 1957).

The annual populations (Poa annua var. annua [L.] Timm.) possess the aforementioned upright, bunch-type growth habit and produce limited numbers of adventitious roots, tillers, and shoots. The annuals also are extremely prolific seedhead producers. The perennial populations (Poa annua var. reptans [Hausskn.] Timm.) have a more prostrate, stoloniferous growth habit and limited seedhead production potential (Beard, 1973). Greens that are managed to favor annual bluegrass have been known to contain extremely fine-textured perennials with population densities approaching 200 shoots $/ \mathrm{cm}^{2}$, with little or no seedhead production, resulting in a high quality putting surface (Turgeon and Keller, 2001).

Annual bluegrass is an invasive weed in creeping bentgrass putting greens, but by understanding the competitive relationship between the two species, new control strategies can be developed to promote more desirable stands of turfgrass. The objectives of this study were to assess the competitive ability of annual bluegrass both in and out of its native habitat, specifically from two locations with distinctly different climates within the state of Ohio, and to determine if the lateral spread of annual bluegrass populations was affected by the particular climate in which they were grown.

\section{Materials and Methods}

A study was initiated on 11 Apr. 2000 at The Country Club in Cleveland, Ohio, and on 20 Apr. 2000 at Camargo Club in Cincinnati, Ohio, to evaluate the competitive ability of annual bluegrass. The study was terminated on 5 Nov. 2001. Cleveland lies at $41^{\circ} 24^{\prime}$ north latitude and $81^{\circ} 51^{\prime}$ 'west longitude. Cincinnati lies at $39^{\circ} 06^{\prime}$ north latitude and $84^{\circ} 25^{\prime}$ 'west longitude. During the study period in 200 and 2001 the average annual maximum temperature in Cleveland was $14.6{ }^{\circ} \mathrm{C}$ and the average annual minimum was $5.2{ }^{\circ} \mathrm{C}$. The average annual maximum temperature in Cincinnati was $18.3^{\circ} \mathrm{C}$ and the average annual minimum temperature was $6.2^{\circ} \mathrm{C}$.

Both at Cleveland and Cincinnati, the greens were originally established (in 1926) as push-up style greens with native soil root zones [Mahoning silt loam (fine, illitic, mesic Aeric Epiaqualf) and Rossmoyne-Urban land silt loam, respectively]. Since establishment, the root zones have been modified to contain a large percentage of sand ( $80 \%$ sand, $20 \%$ topsoil) through periodic topdressing. Currently both courses topdress with $100 \%$ mason 
sand ( $>90 \%$ of particles in 0.18 to $0.50 \mathrm{~mm}$ size range). The species makeup of each green consists of a mixture of annual bluegrass and creeping bentgrass. The greens originally were established with a German mixture of bentgrasses (Beard, 1973) and over the years have been periodically overseeded with various bentgrass cultivars including 'Lopez', 'Southshore', 'Dominant', 'Penncross', 'A-1', 'G-2', and 'L-93'. Annual bluegrass, however, has become well established and now predominates on the greens at both sites and it is maintained as the dominant species.

Greens were irrigated throughout the growing season to avoid wilt and were maintained daily at a $3.125 \mathrm{~mm}$ mowing bench height of cut, but occasionally as low as $2.875 \mathrm{~mm}$. Grass clippings were collected and removed each time the greens were mowed. The plots received traffic from daily golf use as well as from normal maintenance operations. Pesticides were applied on a preventative basis and no disease symptoms were observed on the research plots throughout the duration of the study. At Cleveland, nitrogen was applied at an average rate of $25.67 \mathrm{~kg} \cdot \mathrm{ha}^{-1}$ per month during the growing season from 9 May 2000 to 28 Nov. 2000, and at an average rate of $28.50 \mathrm{~kg} \cdot \mathrm{ha}^{-1}$ per month from 3 May 2001 to 19 Nov. 2001. At Cincinnati, nitrogen was applied at a rate of $13.01 \mathrm{~kg} \cdot \mathrm{ha}^{-1}$ per month during the growing season from 27 Apr. 2000 to 11 December 2000, and at a rate of 14.99 $\mathrm{kg} \cdot \mathrm{ha}^{-1}$ per month from $25 \mathrm{Apr} .2001$ to 27 Nov. 2001

The experimental design was similar at both Cleveland and Cincinnati. Using a standard golf course hole cutter (Par Aide Products Co., Lino Lakes, Minn.), 72 10.2-cm-diameter plugs of annual bluegrass were randomly selected and pulled from greens $1,3,4,5,10,11,12,15$, 16 , and 17 at Cleveland, and from greens 1,2 , $3,4,5,6,10,11,12,13$, and 14 at Cincinnati and placed into a $10.2-\mathrm{cm}$-diameter piece of schedule 40 polyvinyl chloride (PVC) pipe to eliminate root competition between species. Each piece of PVC pipe was $15 \mathrm{~cm}$ long. Plugs were fitted into the top of the PVC pipe such that the bottom of the thatch layer of each plug was in line with the top of the pipe. Using the same topdressing mix that was regularly applied to each green, plugs were inverted and any open space in the bottom of the PVC pipe was filled so that the entire piece of pipe contained rootzone mix. A piece of fiberglass screen (Phifer Wire Products, Inc., Tuscaloosa, Ala.) was glued to the bottom of each plug so as to allow water to pass through but still hold the rootzone mix in place while plugs were being transported and reestablished. Each plug was turned right-side up, irrigated, and then carefully scrutinized to be certain that each one contained a solid stand of annual bluegrass. Any foreign species were physically removed from the stand using tweezers and/or a utility knife. During this time, plugs continued to be irrigated, topdressed, and mowed using electric hand clippers (Wahl Clipper Corp., Sterling, Ill.) for 1 week.

Upon completion of the selection and insertion of each plug into the PVC pipe, thirtysix plugs were randomly selected and then transported to the opposite location (foreign samples). At each location, the foreign samples were established into three randomly selected greens. Thirty-six plugs that were left at their original location also were reestablished into three randomly selected greens. The plugs were reestablished and maintained for the next 2 years in the PVC tubes in order to eliminate root competition between the two species. However, the plugs were set into the soil so that the top of the PVC tube was just below the soil surface so as to not interfere with stem (stolon, tiller) growth. As each plug of annual bluegrass was reestablished, it was centered into a 20.3-cm-diameter stand of 'L-93' creeping bentgrass sod that was cut $2.5 \mathrm{~cm}$ thick to provide equal starting conditions for taking measurements. The 'L-93' creeping bentgrass was grown on a $100 \%$ sand rootzone $(>90 \%$ of particles in 0.18 to $0.50 \mathrm{~mm}$ size range) and was obtained from Sand Ridge Golf Club in Chardon, Ohio [Chili loam soil (fine, loamy, mixed-mesic Typic Hapludalfs)]. Each stand of annual bluegrass centered in its respective stand of creeping bentgrass shall hereafter be referred to as a subsample.

The 72 annual bluegrass/creeping bentgrass subsamples were established in a randomized complete-block design with two blocking criteria (one nested in the other), and with subsampling. Each green comprised the first blocking criterion. Nested within each green were six mini-blocks. Each mini-block contained two subsamples (the sampling unit) from Cleveland and two from Cincinnati, randomly arranged within the mini-block.
Essentially, there were 12 sampling units per green per location. Mini-blocks were kept at the periphery of the greens to avoid interference with daily golf pin locations, but were inside the clean-up pass area.

Competitive ability of each subsample was determined by comparing the average spread of each plug of annual bluegrass throughout the growing season. The measuring process consisted of placing a compass over the annual bluegrass stand to find the north-south $(\mathrm{N}-\mathrm{S})$ axis. A ruler was placed under the compass such that it lay along the diameter of the plug along the $\mathrm{N}-\mathrm{S}$ axis. That diameter was measured and recorded as the $\mathrm{N}-\mathrm{S}$ diameter. The compass then was removed and a protractor was placed on the ruler so that its origin was located at half of the $\mathrm{N}-\mathrm{S}$ diameter and the ruler was lined up with $90^{\circ}$ on the protractor. The ruler then was removed and placed along the 0 to $180^{\circ}$, or east-west (E-W), axis and that diameter was measured and recorded as the E-W diameter. This procedure was repeated along the 45 to $225^{\circ}$ (NE-SW) axis, as well as the 135 to $315^{\circ}$ (NW-SE) axis. The four diameters then were averaged to obtain a single diameter for each subsample. Finally, the two diameters that were obtained for each subsample from a location that were in a particular mini-block were averaged, resulting in twelve total diameters per green, six from Cleveland and six from Cincinnati.

Measurements were taken in Cincinnati beginning on 23 May 2000 and in Cleveland on 1 June 2000. Diameters initially were measured biweekly until September, and then monthly through November, when snow cover prohibited further measurements until the following spring. In 2001, measurements were initiated on 4 Apr. 2001 in Cincinnati and on 9 Apr. 2001 in Cleveland. Diameters were measured on a monthly basis through the month of November in 2001. At the Cincinnati location, the golf course management removed one green, leaving only two blocks at that location for measurements in 2001.

Measurements of the average diameter of each subsample were subjected to analysis of variance using the General Linear Model procedure in the Statistical Analysis System (SAS Institute, 1990). Year 2000 and 2001 data were analyzed separately, as the established stands persisted on a yearly basis and measurements were taken over time. Means are presented as

Table 1. Average diameter $(\mathrm{cm})$ of annual bluegrass plugs from two populations as affected by location in 2000 .

\begin{tabular}{|c|c|c|c|c|c|c|c|c|c|c|c|}
\hline \multirow[b]{2}{*}{ Population } & \multirow[b]{2}{*}{ df } & \multirow[b]{2}{*}{ Location } & \multicolumn{9}{|c|}{ Plug diam $(\mathrm{cm})$} \\
\hline & & & $\begin{array}{l}\text { Early } \\
\text { June }^{z}\end{array}$ & $\begin{array}{l}\text { Late } \\
\text { June }^{y}\end{array}$ & $\begin{array}{c}\text { Early } \\
\text { July }\end{array}$ & $\begin{array}{l}\text { Late } \\
\text { July }\end{array}$ & $\begin{array}{l}\text { Early } \\
\text { Aug. }\end{array}$ & $\begin{array}{l}\text { Late } \\
\text { Aug. }\end{array}$ & Sept. & Oct. & Nov. \\
\hline Cleveland & & Cleveland & 11.0 & 11.1 & 11.1 & 10.8 & 11.0 & 10.7 & 10.8 & 11.2 & 10.3 \\
\hline Cincinnati & & Cincinnati & 10.8 & 11.0 & 11.0 & 10.8 & 10.8 & 10.6 & 10.7 & 10.9 & 11.1 \\
\hline \multicolumn{12}{|l|}{ Source of variation } \\
\hline Location & 1 & & NS & NS & NS & NS & NS & NS & NS & NS & $* *$ \\
\hline Location $\times$ population & 1 & & ** & * & ** & NS & NS & NS & NS & NS & NS \\
\hline
\end{tabular}

${ }^{2}$ Measurements taken between the 1 st and 15 th of the month.

${ }^{y}$ Measurements taken between the 16th and 30th (or 31st) of the month.

NS,*,**,****Nonsignificant or significant at $P=0.05,0.01$, or 0.001 , respectively. 
Table 2. Average diameter $(\mathrm{cm})$ of annual bluegrass plugs from two populations as affected by location in 2001 .

\begin{tabular}{|c|c|c|c|c|c|c|c|c|c|c|}
\hline \multirow[b]{2}{*}{ Population } & \multirow[b]{2}{*}{$\mathrm{df}$} & \multirow[b]{2}{*}{ Location } & \multicolumn{8}{|c|}{ Plug diam $(\mathrm{cm})$} \\
\hline & & & April & May & June & July & Aug. & Sept. & Oct. & Nov. \\
\hline Cleveland & & Cleveland & 8.4 & 9.2 & 8.3 & 8.6 & 7.7 & 6.3 & 6.6 & 7.1 \\
\hline Cleveland & & Cincinnati & 9.8 & 9.4 & 9.2 & 8.2 & 7.9 & 6.8 & 5.1 & 4.7 \\
\hline Cincinnati & & Cleveland & 8.3 & 10.1 & 9.0 & 9.1 & 8.8 & 6.6 & 6.4 & 6.6 \\
\hline Cincinnati & & Cincinnati & 9.2 & 9.1 & 9.4 & 8.5 & 8.4 & 7.2 & 7.1 & 7.0 \\
\hline \multicolumn{11}{|l|}{ Source of variation } \\
\hline Location & 1 & & $*$ & NS & NS & NS & NS & NS & NS & $*$ \\
\hline Green (location) & 4 & & NS & NS & $*$ & $*$ & $* *$ & $*$ & $* *$ & $* *$ \\
\hline Population & 1 & & NS & NS & NS & NS & $*$ & NS & NS & NS \\
\hline Location $\times$ population & 1 & & NS & NS & NS & NS & NS & NS & $*$ & $*$ \\
\hline
\end{tabular}

NS,*,******Nonsignificant or significant at $P=0.05,0.01$, or 0.001 , respectively.

the location $\times$ population interaction. No mean separation procedures were performed because the analysis is of single degree of freedom terms or interactions only. Initial analysis of year 2000 data found neither the subsampling variability nor the variability between miniblocks to be significant, so the data from each green were subsequently pooled.

\section{Results and Discussion}

There were no location differences between Cleveland and Cincinnati until November, 2000 when mean annual bluegrass diameters were $8.4 \%$ larger at Cincinnati (Table 1 ). Location differences were also recorded in April and November 2001 (Table 2). In April, Cincinnati mean plug diameters were $11.5 \%$ larger than in Cleveland. In November, however, the Cleveland mean plug diameters were $14.6 \%$ larger than in Cincinnati.

The overall lack of differences between the locations was likely due to the fact that at each location the native population of annual bluegrass outperformed the imported population. The differences that were seen in November 2000 can be attributed to the fact that the average daily temperature in Cleveland was $2.68^{\circ} \mathrm{C}$ colder between the October and November measurements. Likewise, in 2001, differences in the April measurements can be ascribed to the fact that Cincinnati was $3.85^{\circ} \mathrm{C}$ warmer than Cleveland in the month leading up to the April measurements. In November, however, Cincinnati was only $1.31^{\circ} \mathrm{C}$ warmer than Cleveland in the month leading up to the November measurements $\left(12.87\right.$ and $11.56^{\circ} \mathrm{C}$, respectively), and yet differences $(P=0.05)$ still existed. It should be noted that temperatures in Cincinnati were below normal and not typical of the transition zone during the summer in both 2000 and 2001.

The most frequent occurrence of significant $(P<0.05)$ differences in this study was in the variability between greens within a particular location. Four out of the nine measurement periods in 2000 and six out of the eight measurement periods in 2001 showed significant $(P=0.01)$ differences between the growth of annual bluegrass plugs on greens at a particular location (Tables 1 and 2). This was likely due to the presence of what could be described as a favorable growing environment (shaded, higher traffic) for annual bluegrass as well as an unfavorable growing environment (full sun, less traffic) at each location. These microclimate differences between greens at each location probably accounted for the differences seen in both years of the study. In general, the annual bluegrass plugs receded in size and relatively few expanded. Mean annual bluegrass diameters ranged between 10 and $12 \mathrm{~cm}$ in 2000 and between 4 and $11 \mathrm{~cm}$ in 2001 . This may have been due to the competitiveness of the 'L-93' bentgrass. However, we observed that the 'L-93' receded on some of the greens that were in shaded environments.

Population differences only were significant $(P=0.05)$ in October 2000 and August 2001. In October 2000, the plugs that originated in Cleveland were on average 3.2\% larger than those originating in Cincinnati (Table 1). In August 2001 the plugs that originated in Cincinnati were on average $9.7 \%$ larger than those originating in Cleveland (Table 2). Although statistically significant, this is not an ecologically significant difference. Since each population was cultivated both in and out of its native habitat, it would be reasonable to expect that the population would perform at least adequately within its native habitat and substantially less than adequate at the opposite location, again negating any differences between populations.

Differences $(P<0.05)$ in the location $\times$ population interaction were seen at both the beginning and the end of the study (Tables 1 and 2). After the initial differences in early June, late June, and early July 2000, there were no differences again until the final two measurement periods: October and November 2001. In early June, the plugs from the Cleveland population that also were located in Cleveland were $3.9 \%$ larger on average than those from the Cincinnati population located in Cleveland. At Cincinnati, those plugs that originated in Cincinnati were $3.0 \%$ larger than those of the Cleveland population. In late June, the Cleveland population outgrew the Cincinnati population at Cleveland by $2.2 \%$ on average. The Cincinnati population averaged $2.3 \%$ larger diameters than the Cleveland population at Cincinnati. In early July, the Cleveland population averaged $2.9 \%$ larger plugs than the Cincinnati population at Cleveland. AtCincinnati, the population originating in Cincinnati had, on average, $2.3 \%$ larger plugs than the Cleveland population (Table 1). Many of these early differences, though statistically significant, were not ecologically significant.

One possible explanation for the differences initially is that the plugs that were transplanted (either from Cleveland to Cincinnati, or vice versa) were subject to a slightly higher degree of stress before establishment. They were out of the ground longer and subjected to stresses due to transportation. As a result, those plugs may have required more time to acclimate to the new habitat following establishment. Another explanation would be that the imported populations required a certain amount of time to acclimate to the new environment.

In the October and November 2001 measurement periods, significant $(P=0.05)$ differences existed in the growth of populations as affected by location (Table 2). The October measurement period showed that the average spread of plugs originating in Cleveland was $3.2 \%$ larger than the average of those originating in Cincinnati, when grown at Cleveland. At Cincinnati, on the other hand, the population originating in Cincinnati was $29.0 \%$ larger on average than the population originating in Cleveland. In November, the plugs originating from Cleveland and grown at the Cleveland location were on average $6.4 \%$ larger than those originating in Cincinnati. At Cincinnati, the average spread of the plugs originating from Cincinnati was $32.6 \%$ larger than the plugs originating from Cleveland.

Between the first three measurement periods in 2000 and the last two in 2001, no differences were seen in the location $\times$ population interaction. While the climates for Cleveland and Cincinnati are considered different, there may not have been enough of a difference between the climates for the populations that were moved to a different location to genuinely be considered out of their native habitats. One possible explanation for the differences in the location $\times$ population interaction at the end of the study is that they were the beginning of a pattern that would have been more fully exposed had the study been continued for at least two more growing seasons. Some turfgrass processes and/or relationships take several years to fully develop (Turgeon, personal communication, 2002). It is possible that for one population to be naturally selected over the other a period of study greater than 2 years may be necessary. In a similar study by Turgeon (2001) in which 10-cm-diameter plugs of annual bluegrass were inserted into swards of various creeping bentgrass cultivars, significant differences between the lateral spread of the annual bluegrass plugs did not manifest themselves until the third and fourth year. Allard (1960) reported that in bulkbreeding studies that have been performed on cultivars of barley (Hordeum vulgare L.), natural selection often took more than four 
years to eliminate poorer competitors. If two genotypes had remarkably different competitive abilities, then the poorer competitor was rapidly eliminated over the first several years. However, even the poorest competitors were slow to disappear. When differences in competitive abilities were small, the elimination of the poorer competitor was slow to take place at first, and even slower later.

Results indicated that possible differences between annual bluegrass populations grown in different locations might have been more pronounced had the study been initiated in a different manner.

In this particular study, competition was limited to aerial portions of the plant (tillers and stolons). Root competition was completely eliminated between the annual bluegrass samples and creeping bentgrasses. It would be interesting to eliminate above ground competition, and allow for root competition. Another method for improving the experimental design would be to use locations with greater climatological differences. It was initially believed that the transition zone climate of Cincinnati and the temperate climate of Cleveland would provide enough difference to affect the growth of annual bluegrass. However, these results indicate that these locations may not have had a large enough difference in climates.

\section{Literature Cited}

Allard, R.W. 1960. Bulk-population breeding. p. 129-149. In: R.W. Allard. Principles of plant breeding. John Wiley, New York.

Beard, J.B. 1970. An ecological study of annual bluegrass. USGA Green Section Record 8(2):13-18.

Beard, J.B. 1973. Turfgrass: Science and culture. Prentice-Hall Inc., Englewood Cliffs, N.J.

Christians, N. 1998. Fundamentals of turfgrass management, p. 33-38. Ann Arbor Press, Chelsea, Mich.

Cline, V.W., D.B. White, and H. Kaerwer. 1993. Observations of population dynamics on selected annual bluegrass-creeping bentgrass golf-greens in MN. Intl. Turfgrass Soc. Res. J. 7:839-844.

Fenner, M. 1985. Seed ecology, p. 45. Chapman and Hall, New York.
Gibeault, V.A. 1970. Perenniality in Pоа аппиа L. $\mathrm{PhD}$ diss. Ore. State Univ., Corvalis.

Gibeault, V.A. and N.R. Goetze. 1973. Annual meadowgrass. J. Sports Turf Res. Inst. 48:9-19.

Hovin, A.W. 1957. Variations in annual bluegrass. Golf Course Rptr. 25(7):18-19.

Lush, W.M. 1988a. Biology of Pоа аппиа in a temperate zone golf putting green (Agrostis stolonifera/Poa аппиа) I. The above-ground population. J. Appl. Ecol. 25:977-988.

Lush, W.M. 1988b. Biology of Poа аппиа in a temperate zone golf putting green (Agrostis stolonifera/Poa аппиа) II. The seed bank. J. Appl. Ecol. 25:989-997.

Lush, W.M. 1989. Adaptation and differentiation of golf course populations of annual bluegrass (Роа аппиа). Weed Sci. 37:54-59.

Lush,W.M. 1990. Biology of Роа аппиа-The secret of success. N.Z. Turf Mgt. J. (Aug.):5-7.

SAS Institute. 1990. SAS user's guide: Statistics. 4th ed. SAS Inst., Cary, N.C.

Turgeon, A.J. and J.L. Keller. 2001. Creeping bentgrass-annual bluegrass competition. In: 2001 Annual meeting abstracts [ASA/CSSA/SSSA]. ASA, Madison, Wis.

Tutin, T.G. 1957. A contribution to the experimental taxonomy of Роа аппиа L. Watsonia 4:1-10. 